\title{
Inflammatory Mediators and Hormonal Changes in Subclinical and Clinically Affected Mastitis Cows
}

\author{
Rachana Sharma*, Manju Ashutosh, Panjab Singh, Sujata Pandita and Mahendra Singh \\ National Dairy Research Institute (NDRI), Karnal, Haryana 132001, India \\ *Corresponding author
}

\author{
A B S T R A C T
}

\begin{tabular}{|l|}
\hline K e y w o r d s \\
NO, TNF- $\alpha$, IL-8, \\
$\begin{array}{l}\text { Cortisol, Progesterone, } \\
\text { PGFM, Subclinical } \\
\text { mastitis and Clinical } \\
\text { mastitis. }\end{array}$ \\
\hline Article Info \\
\hline $\begin{array}{l}\text { Accepted: } \\
\text { 07 September } 2017 \\
\text { Available Online: } \\
\text { 10 November } 2017\end{array}$ \\
\hline
\end{tabular}

\section{Introduction}

Dairy animals encounter mastitis as one of the most important disease causing hindrance in the development of dairy sector. Selective breeding of dairy cattle has led to a dramatic increase in milk yield over recent decades giving India an honour to become the highest milk producer country in the world but simultaneous increase in high incidence of mastitis and huge economic losses have been reported (Heald et al., 2000; Seegers et al., 2003; Oltenacu and Algers, 2005). Researchers agree that the economic impact of subclinical forms of mastitis is larger than clinical mastitis (Singh et al., 2016). The overall prevalence of sub-clinical mastitis has been reported to be $59.43 \%$ with quarter level prevalence of $34.78 \%$ (Bhat et al., 2016). The annual economic losses due to mastitis have been calculated to be Rs.7165.51 crores both cows and buffaloes almost with rupees 3649.56 and 3515.95 crores, respectively (PDAMAS, 2011). Subclinicacl mastitis alone causes economic losses of rupees 4151.16 crores (Bogni et al., 2011). This could be minimized by using certain makers in milk and plasma of mastitis animals. It has been found that nitric oxide (NO), interleukins (IL) and tumor necrosis factor (TNF- $\alpha$ ) could play a vital role in the pathophysiology of this (Kushibiki et al., 2003; Hansen et al., 2004). 
Mastitis not only influence milk production and composition but adversely influence reproductive performance of dairy cows (Schrick et al., 2001; Santos et al., 2004; Hansen et. al., 2004) as homeostatic alterations in hormone viz., prostaglandin, progesterone and estrogen affects oocyte maturation, follicular development, luteal life span, resulting the embryonic losses, increased service period and more number of AI per conception and days open. Enhanced cortisol depressed LH and thereby affects ovulation process ( $\mathrm{Li}$ et al., 1983; Padmanabhan et al., 1983). Considering the economic losses due to mastitis, the present investigation was undertaken to find out plasma inflammatory mediators of infection and hormone levels in mastitis crossbred cows.

\section{Materials and Methods}

\section{Selection of Animals and management}

The experiment was conducted after getting necessary approval from the Institute's Animal Ethics Committee. 32 Karan Fries cows immediately after parturition were selected from the experimental herd of the Institute. These were divided into three groups of eight each as healthy, SCM and CM animals. The cows were grouped based on screening by California Mastitis Test (mCMT) and milk SCC. Healthy cows during the experiment served as control while cows suffering from sub clinical mastitis were in SCM group. Eight cows suffering from clinical mastitis were also selected on the basis of clinical symptoms from which milk samples were taken only once.

The animals were managed in loose housing with brick floor and asbestos roof shed over the feeding manger. Cows were fed ad lib green fodder (berseem, maize and jowar fodder) and wheat straw and the concentrate mixture was offered based on milk yield. The feed and water was available ad lib all the time to these cows. Blood samples were collected in heparinized vacutainer tubes from healthy and SCM cows at weekly intervals from $54^{\text {th }}$ day to 138 days of lactation. A single blood sample was also collected from clinical mastitis cows before treatment of cows with antibiotic.

Plasma nitric oxide (NO) was determined by method of Shoker et al., (1997). Plasma tumor necrosis factor- $\alpha$ (TNF- $\alpha$ ), interleukin-8 (IL-8), progesterone, cortisol and PGFM (prostaglandin $\mathrm{F}_{2} \quad-\alpha$ ) were estimated by commercially available analytical ELISA kits.

The data was analyzed statistically by a SYSTAT software package. Mean \pm SE was found and the significance was tested by employing two way ANOVA.

\section{Results and Discussion}

\section{Inflammatory mediators}

Plasma NO level was higher in CM cows in comparison to SCM and healthy group cows (Table 1 and 2). Significantly higher plasma NO level has been reported earlier Bastan et al., (2011) in cows with mastitis. The concentration tended to increase massively during bacterial infections. The research experiment carried out in vitro and in vivo also suggests that NO concentrations increase during clinical infections being induced with E. coli endotoxin and Staphylococcus spp. (Blum et al., 2000; Boulanger et al., 2001; Blum et al., 2003; Komine et al., 2004). Further bovine PMN have also been considered the source of NO production by (Boulanger et al., 2001; Komine et al., 2004).

Mean plasma TNF- $\alpha$ level was more $(p<0.001)$ in healthy and SCM groups of 
cows. Plasma TNF- $\alpha$ levels varied $(\mathrm{P}<0.001)$ between the groups. TNF- $\alpha$ is released locally in mammary gland of mastitis cows and its absorption into the circulation elevates plasma concentration (Hoeben et al., 2000). These cytokine induced and mediated neural and endocrine changes play key roles in the induction of systemic symptoms of mastitis, e.g. fever, lethargy, loss of appetite (anorexia) and many catabolic changes in energy (lipid, carbohydrate), protein and mineral metabolism (Huszenicza et al., 2004). Plasma TNF- $\alpha$ concentrations increase within hours after i.v. administration of LPS, in E. coliinduced mastitis and in natural cases of coliform mastitis, in cattle (Hirvonen et al., 1999; Kinsbergen et al., 1994), and TNF- $\alpha$ production initiates immunological and metabolic reactions which could be detrimental locally (Hirvonen et al., 1999). Further large quantities of LPS must be produced continuously to induce and elevated TNF- $\alpha$ concentrations in blood because i.v. administration of LPS causes a transient rise of TNF- $\alpha$ in cattle (Kinsbergen et al., 1994: Kahl et al., 1997). Severe cases of coliform mastitis are accompanied by the highest increase in blood plasma concentrations of both TNF- $\alpha$ and NO (Kahl et al., 1997; Hirvonen et al., 1999; Blum et al., 2000;
Komine et al., 2004). Elevated TNF $\alpha$ in blood of mastitis animals (Blum et al., 2000, Hoeben et al., 2000; Ohtuska et al., 2001) can increase $\mathrm{PGF}_{2} \alpha$ synthesis (Starzynski et al., 2000) and suppress LH surge leading to inhibition of fertilization and development of embryos (Hansen et al.,2004).

Plasma IL-8 levels varied $(\mathrm{p}<0.001)$ between groups. The levels were significantly $(\mathrm{P}<0.001)$ higher in $\mathrm{CM}$ cows as Compared to the SCM and healthy cows (Table 2). Kim et al., (2011) concluded that significant $(\mathrm{P}<0.001)$ IL-8 expression in the serum was not evident for any infected groups of Holstein cows 14 days post infection. Therefore it can be concluded that increased secretion of IL-8 is an important maker of inflammatory processes. Interleukin 8 (IL-8) is a chemokine produced by macrophages and other cell types such as epithelial cells and neutrophils. Several studies have confirmed higher IL-8 level in E. coli infected mastitis cows as compared with healthy glands (Riollet et al., 2000; Lee et al., 2003b; Bannerman et al., 2004c; Vangroenweghe et al., 2004, 2005).

Plasma cortisol levels varied non-significant between the group of cows and between days.

Fig.1 Mean plasma cortisol levels in healthy and subclinical mastitis cows during lactation

Fig.2 Overall mean cortisol levels in different groups of lactating Cows
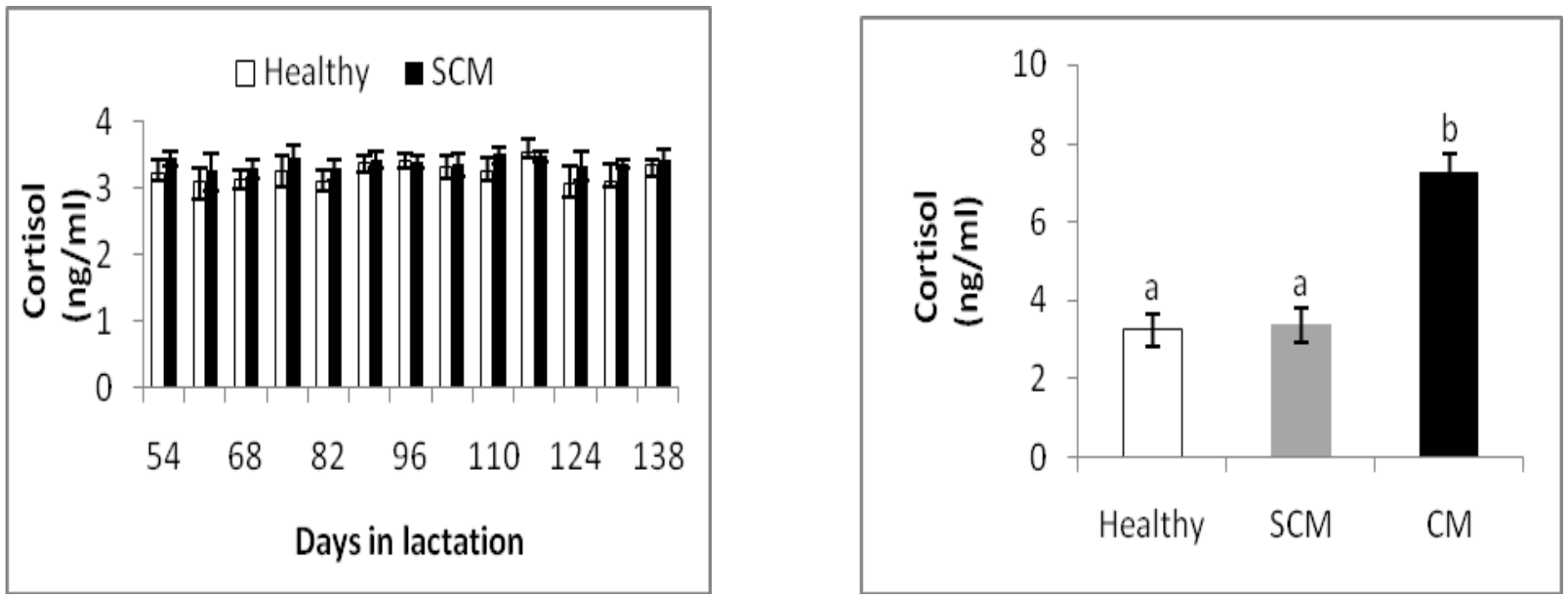
Fig.3 Mean plasma progesterone levels in healthy and subclinical mastitis cows during lactation, Fig.4 Overall mean progesterone levels in different groups of lactating cows
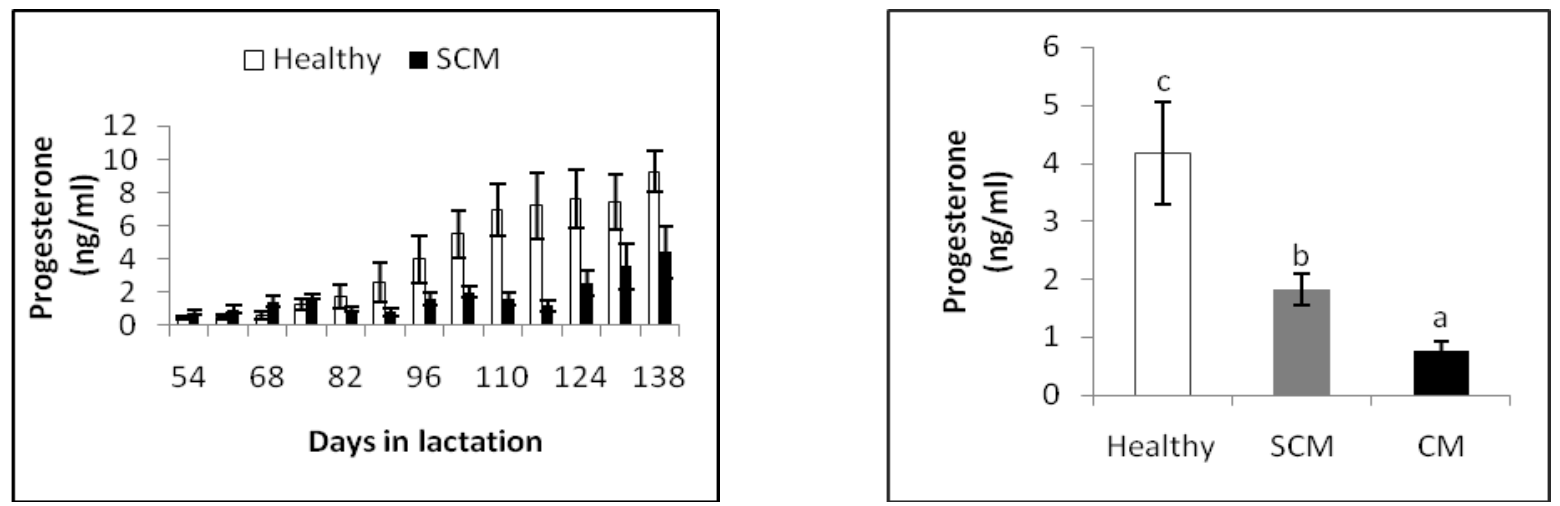

Fig.5 Mean plasma prostaglandin $\mathrm{F}_{2}-\alpha$ levels in healthy and subclinical mastitis cows during lactation, Fig.6 Overall mean prostaglandin $\mathrm{F}_{2}-\alpha$ levels in different groups of lactating cows
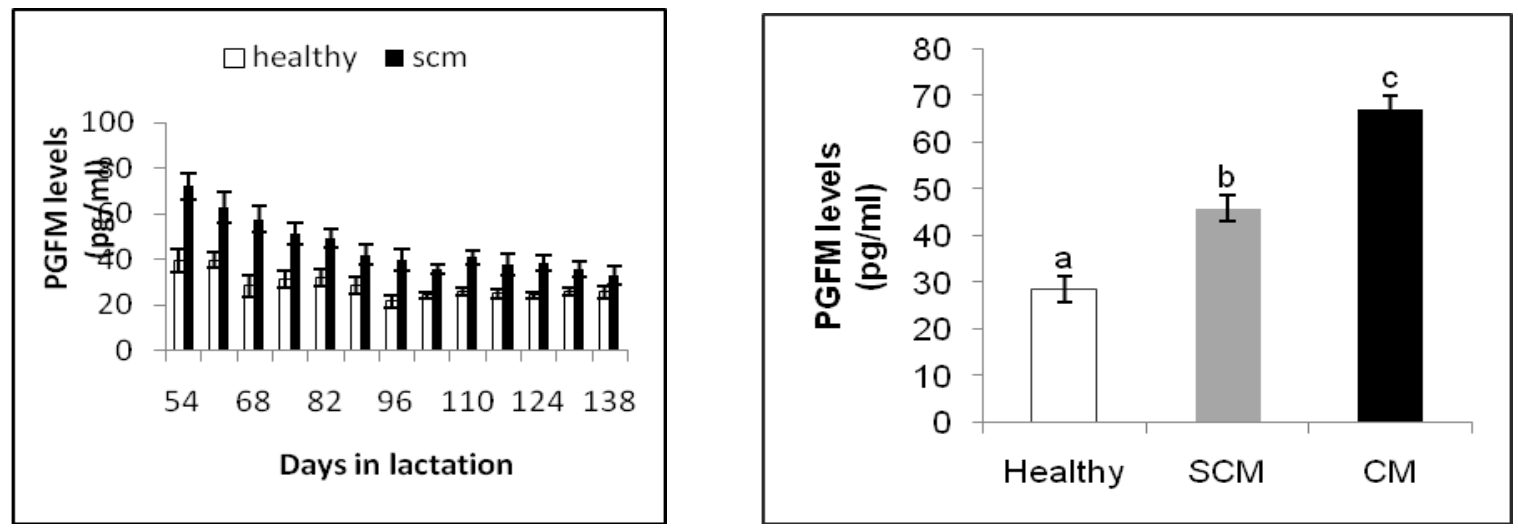

Table.1 Mean plasma NO ( $\mu \mathrm{mol} / \mathrm{L})$, TNF- $\alpha(\mathrm{pg} / \mathrm{ml})$ and IL-8 $(\mathrm{pg} / \mathrm{ml})$ levels in healthy and subclinical mastitis cows during lactation

\begin{tabular}{|c|l|l|l|l|l|l|}
\hline \multirow{2}{*}{$\begin{array}{c}\text { Mediators } \\
\text { Postpartum Days }\end{array}$} & \multicolumn{2}{|c|}{ Nitric Oxide (NO) } & \multicolumn{2}{l|}{ Tumor Necrosis Factor- $\boldsymbol{\alpha}$ (TNF- $\boldsymbol{\alpha}$ ) } & \multicolumn{2}{c|}{ Interleukin-8 (IL-8) } \\
\cline { 2 - 7 } & Healthy & SCM & Healthy & SCM & Healthy & SCM \\
\hline $\mathbf{5 4}$ & $35.75^{\mathrm{a}} \pm 1.06$ & $38.03^{\mathrm{a}} \pm 1.6$ & $48.74^{\mathrm{Aa}} \pm 4.33$ & $197.69^{\mathrm{Ab}} \pm 6.58$ & $7.43^{\mathrm{a}} \pm 0.36$ & $7.97^{\mathrm{a}} \pm 0.43$ \\
\hline $\mathbf{6 1}$ & $35.17^{\mathrm{a}} \pm 1.08$ & $37.3^{\mathrm{a}} \pm 1.25$ & $50.5^{\mathrm{Aa}} \pm 3.51$ & $197.01^{\mathrm{Ab}} \pm 7.27$ & $7.64^{\mathrm{a}} \pm 0.39$ & $8.17^{\mathrm{a}} \pm 0.46$ \\
\hline $\mathbf{6 8}$ & $35.62^{\mathrm{a}} \pm 1.03$ & $37.59^{\mathrm{a}} \pm 1.35$ & $51.54^{\mathrm{Aa}} \pm 3.95$ & $197.47^{\mathrm{Ab}} \pm 4.40$ & $7.97^{\mathrm{a}} \pm 0.36$ & $8.36^{\mathrm{a}} \pm 0.43$ \\
\hline $\mathbf{7 5}$ & $35.36^{\mathrm{a}} \pm 1.24$ & $37.31^{\mathrm{a}} \pm 1.24$ & $50.40^{\mathrm{Aa}} \pm 3.66$ & $196.04^{\mathrm{Ab}} \pm 11.59$ & $7.49^{\mathrm{a}} \pm 0.37$ & $8.16^{\mathrm{a}} \pm 0.45$ \\
\hline $\mathbf{8 2}$ & $34.69^{\mathrm{a}} \pm 1.24$ & $36.56^{\mathrm{a}} \pm 1.05$ & $54.30^{\mathrm{Aa}} \pm 2.94$ & $185.19^{\mathrm{Ab}} \pm 4.46$ & $7.06^{\mathrm{a}} \pm 0.48$ & $7.76^{\mathrm{a}} \pm 0.30$ \\
\hline $\mathbf{8 9}$ & $35.47^{\mathrm{a}} \pm 0.95$ & $37.14^{\mathrm{a}} \pm 0.90$ & $57.04^{\mathrm{Aa}} \pm 2.39$ & $179.87^{\mathrm{Ab}} \pm 4.39$ & $6.92^{\mathrm{a}} \pm 0.88$ & $8.08^{\mathrm{a}} \pm 0.46$ \\
\hline $\mathbf{9 6}$ & $35.18^{\mathrm{a}} \pm 1.34$ & $37.38^{\mathrm{a}} \pm 1.31$ & $58.22^{\mathrm{Aa}} \pm 2.42$ & $177.88^{\mathrm{Ab}} \pm 3.96$ & $7.21^{\mathrm{a}} \pm 0.37$ & $8.00^{\mathrm{a}} \pm 0.46$ \\
\hline $\mathbf{1 0 3}$ & $35.21^{\mathrm{a}} \pm 1.66$ & $37.00^{\mathrm{a}} \pm 1.23$ & $54.28^{\mathrm{Aa}} \pm 2.41$ & $163.92^{\mathrm{Ab}} \pm 7.20$ & $7.29^{\mathrm{a}} \pm 0.71$ & $7.94^{\mathrm{a}} \pm 0.43$ \\
\hline $\mathbf{1 1 0}$ & $34.24^{\mathrm{a}} \pm 0.95$ & $36.21^{\mathrm{a}} \pm 1.17$ & $57.17^{\mathrm{Aa}} \pm 2.10$ & $159.87^{\mathrm{Ab}} \pm 7.03$ & $7.21^{\mathrm{a}} \pm 0.59$ & $7.81^{\mathrm{a}} \pm 0.45$ \\
\hline $\mathbf{1 1 7}$ & $33.83^{\mathrm{a}} \pm 1.15$ & $36.08^{\mathrm{a}} \pm 1.20$ & $57.23^{\mathrm{Aa}} \pm 2.16$ & $157.03^{\mathrm{Ab}} \pm 6.37$ & $7.34^{\mathrm{a}} \pm 0.34$ & $7.85^{\mathrm{a}} \pm 0.37$ \\
\hline $\mathbf{1 2 4}$ & $33.5^{\mathrm{a}} \pm 0.61$ & $35.5^{\mathrm{a}} \pm 1.51$ & $56.40^{\mathrm{Aa}} \pm 2.81$ & $145.01^{\mathrm{BEFb}} \pm 7.58$ & $7.63^{\mathrm{a}} \pm 0.46$ & $8.12^{\mathrm{a}} \pm 0.38$ \\
\hline $\mathbf{1 3 1}$ & $33.29^{\mathrm{a}} \pm 1.01$ & $34.46^{\mathrm{a}} \pm 0.93$ & $56.25^{\mathrm{Aa}} \pm 1.57$ & $145.70^{\mathrm{CEFb}} \pm 6.29$ & $7.24^{\mathrm{a}} \pm 0.31$ & $7.82^{\mathrm{a}} \pm 0.36$ \\
\hline $\mathbf{1 3 8}$ & $33.51^{\mathrm{a}} \pm 0.83$ & $34.31^{\mathrm{a}} \pm 1.29$ & $58.08^{\mathrm{Aa}} \pm 2.16$ & $135.78^{\mathrm{DFb}} \pm 11.5$ & $7.20^{\mathrm{a}} \pm 0.24$ & $7.55^{\mathrm{a}} \pm 0.50$ \\
\hline Over all mean \pm SEM & $\mathbf{3 4 . 6 8}^{\mathrm{a}} \pm \mathbf{0 . 2 4}$ & $\mathbf{3 6 . 7 5}^{\mathrm{a}} \pm \mathbf{0 . 3 5 9}$ & $\mathbf{5 4 . 6 3} \pm \mathbf{0 . 9 0}$ & $\mathbf{1 7 1 . 8 0}^{\mathrm{a}} \pm \mathbf{6 . 3 2}$ & $\mathbf{7 . 3 5}^{\mathrm{a}} \pm \mathbf{0 . 1 2}$ & $\mathbf{7 . 9 6} \pm \mathbf{0 . 1 4}$ \\
\hline
\end{tabular}

Values with different superscripts ${ }^{a b}$ and ${ }^{A B C D E F}$ differ $(p<0.05)$ in a row and column respectively 
Table.2 Mean plasma NO, TNF- $\alpha$ and IL-8 levels in different group of cows

\begin{tabular}{|c|c|c|c|}
\hline $\begin{array}{ll}\text { Mediators } & \text { Groups } \\
\end{array}$ & Healthy & SCM & $\mathbf{C M}$ \\
\hline $\mathrm{NO}(\mu \mathrm{mol} / \mathrm{L})$ & $34.68^{a} \pm 0.24$ & $36.75^{\mathrm{a}} \pm 0.359$ & $59.96^{b} \pm 2.53$ \\
\hline TNF- $\alpha(\mathrm{pg} / \mathrm{ml})$ & $54.63^{\mathrm{a}} \pm 0.90$ & $171.80^{b} \pm 6.32$ & $695.50^{c} \pm 43.98$ \\
\hline IL-8(pg/ml) & $7.35^{\mathrm{a}} \pm 0.12$ & $7.96^{\mathrm{a}} \pm 0.14$ & $24.35^{b} \pm 1.19$ \\
\hline
\end{tabular}

Values with different superscripts ${ }^{\text {abc }}$ differ $(\mathrm{p}<0.05)$ in row

However, plasma cortisol level was significantly $(\mathrm{P}<0.001)$ higher in clinical mastitis cows than the healthy and subclinical mastitis cows (Figure 2). Kuldeep, (2011) observed three times higher plasma cortisol levels in clinical mastitis cows. Cortisol act as powerful immunosuppressive agent and facilitates the invasion of environmental pathogens leading to increased incidence of mastitis (Goff and Horst, 1997; Kehrli et al., 1991). Higher cortisol level also suppresses the lymphogenic response to mitogens and certain aspects of neutrophil function (Jacob et al., 2001). This could be the reaction of higher cortisol levels in clinical mastitis cows found in this study (Fig. 1).

Endotoxin challenges also cause higher cortisol level (Soliman et al., 2002; Waldron et al., 2003; Lehtolainen et al., 2003).

The PGFM levels varied significantly $(\mathrm{P}<0.001)$ between healthy, SCM and $\mathrm{CM}$ group cows (Figures 3 and 4). Elevated $\mathrm{PGF}_{2} \alpha$ levels in subclinical and clinical mastitis cows in to comparison to healthy cows, resulted in low progesterone concentration resulting the impaired embryonic development and increased number of services per conception service period and higher oxytocin concentration (Hockett et al., 2000).

Plasma progesterone levels was significantly different $(p<0.001)$ between healthy, SCM and $\mathrm{CM}$ group cows (Figures 5 and 6). Higher levels of progesterone after 75 days of lactation in healthy cows indicated pregnancy status. However, SCM cows rise in progesterone levels was less and occur after 124 days. The confirmed pregnancy percent in healthy and SCM cows was $87.5 \%$ and $75 \%$ respectively. The delay in pregnancy varied significantly $(\mathrm{P}<0.001)$ between the groups.

Based on the results of hormonal and biochemical parameters it was concluded that monitoring of inflammatory markers could be used as a biomarker to identify the cows at high-risk of infection. This will facilitate prompt treatment and pro-active management practices in reducing disease incidence and the dairy farms are likely to improve overall productivity of the animal.

\section{Acknowledgements}

The authors are thankful to the Director of the livestock for providing necessary facilities for the execution of this work. The support extended by the laboratory technician and staff of animal physiology division is duly acknowledged.

\section{References}

Bannerman, D.D., Paape, M.J., Lee, J.W., Zhao, X., Hope, J.C. and Rainard, P. 2004c. Escherichia coli and Staphylococcus aureus elicit differential innate immune responses following intramammary infection. Clin. Diagn. Lab. Immunol., 11:463-472.

Bastan, A., Cengiz, M., Sel, T., Cengiz, S., Akan, M., Akcay, A., Darbaz, I. and 
Fidancei, U. 2011. Evaluation of nitric oxide level in prepartum heifer mastitis. Ankara, univ. Vet. Fak. Derg., 58:181184.

Bhat, A. M., Soodan, J.S. and Tikoo, A. 2016. Study on prevalence of subclinical mastitis in cross bred dairy cattle and its potential risk factors. J. Anim. Res., 6(4): 747-749.

Blum, J.W., Dosogne, H., Hoeben, D., Vangroenweghe, F., Hammon, H.M., Bruckmaier, R.M. and Burvenich, C., 2000. Tumor necrosis factor-b and nitrite/nitrate responses during acute mastitis induced by Escherichia coli infection and endotoxin in dairy cows. Dom. Anim. Endocrinol., 19: 223-235.

Bogni C., Odierno L., Raspanti C., Giraudo J., Lasrriestra A., Reinoso E., Lasagno M., Ferrari M., Ducros E., Frigerioc C., Bettera S., Pellegrino M. S., Forla I., Dieser S. and Vissio C. 2011. War against mastitis pathogens. Science against microbial pathogen. Current research and tehnological advances. A. Mendez-Vilas (Ed.) 483-494

Boulanger, V., Bouchard, L., Zhao, X. and Lacasse, P. 2001. Induction of nitric oxide production by bovine mammary epithelial cells and blood leukocytes. $J$. Dairy Sci., 84: 1430-1437.

Goff, J.P. and Horst, R.L. 1997. Physiological changes at parturition and their relationship to metabolic disorders. $J$. Dairy Sci., 80: 1260-1268.

Hansen, P.J., Paolete S. and Natzke R.P. 2004. Mastitis and fertility in cattlepossible involvement of inflammation or immune activation in embryonic mortality. American Journal of Reproductive Immunology., 51: 294301.

Heald, C.W., Kim, T., Sischo, W.M., Coopper, J.B. and Wolfgang, D.R. 2000. A computerized mastitis decision aid using farm-based records: an artificial neural network approach. $J$. Dairy. Sci. 83 (4):711-722.

Hirvonen, J., Eklund, K., Teppo, A.M., Huszenicza, G., Kulcsar, M., Saloniemi, H., and Pyorala, S. 1999. Acute phase response in dairy cows with experimentally induced Escherichia coli mastitis. Acta. Vet. Scand., 40: 35-46.

Hockett, M.E., Hopkins, F.M., Lewis, M.J., Saxton, A.M., Dowlen, H.H., Oliver, S.P. and Schrick, F.N. 2000. Endocrine profiles of dairy cows following experimentally induced clinical mastitis during early lactation. Anim. Reprod. Sci., 58: 241-251.

Hoeben, D., Burvenich, C., Tervisi, E., Bertoni, G., Hamann, J., Bruckmaier, R.M. and Blum, J.W., 2000. Role of endotoxin and TNF- $\alpha$ in the pathogenesis and experimentally induced colliform mastitis in periparturient cows. J. Dairy Res., 67: 503-514.

Huszenicza, G., Janosi, S., Gaspardy, A. and Kulcsar, M. 2004. Endocrine aspects in pathogenesis of mastitis in postpartum dairy cows. Animal Reproduction Science, 82:389-400

Jacob, S.K., Ramnath, V., Philomina, P.T., Raghunandhanan, K.V. and Kannan, A. 2001. Assessment of Physiological Stress in Periparturient Cows and Neonatal Calves. Indian J. Physiol. Pharmacol., 45 (2): 233-238.

Kahl, S., Elsasser, T.H. and Blum, J.W. 1997. Nutritional regulation of plasma TNF-a and plasma and urinary nitrite nitrate responses to endotoxin in cattle. Proc. Soc. Exp. Biol. Med., 215: 370-376.

Kehrli, M.E., Weigel, K.A., Freeman, A.E., Thurston, J.R. and Kelley, D.H. 1991. Bovine sire effects on daughter's in vitro blood neutrophil functions, lymphocyte blastogenesis, serum complement and conglutinin levels. Vet. Immunol. Immunopathol., 27: 303-319. 
Kim, Y., Atalla, H., Mallard, B., Robert, C. and Karrow, N. 2011. Changes in Holstein cow milk and serum proteins during intramammary infection with three different strains of Staphylococcus aureus. BMC Vet. Res. 7:51.

Kinsbergen, M., Bruckmaier, R.M. and Blum, J.W. 1994. Metabolic, endocrine and hematological responses to E. coli endotoxin administration in one-week old calves. J. Vet. Med., 41: 530-547.

Komine, K., Kuroishi, T., Komine, Y., Watanabe, K., Kobayashi, J., Yamaguchi, T., Kamata, S. and Kumagai, K. 2004. Induction of nitric oxide production mediated by tumor necrosis factor alpha on staphylococcal enterotoxin c-stimulated bovine mammary gland cells. Clinical and Diagnostic Laboratory Immunology. 11: 203-210.

Kuldeep. 2011. Studies on immunological variables and nitric oxide synthase (iNOS) expression during different stages of lactation and mastitis in crossbred cattle. M.V.Sc. Thesis, NDRI (deemed University), Karnal, India.

Kushibiki, S., Hodate, K., Shingu, H., Obara, Y., Touno, E., Shinoda, M. and Yokomizo, M., 2003. Metabolic and lactational responses during recombinant bovine tumor necrosis factor-a. J. Dairy Sci., 86: 819-827.

Lee, J.W., Paape, M. J., Elsasser, T.H. and Zhao, X. 2003b. Recombinant soluble CD14 reduces severity of intramammary infection by Escherichia coli. Infect. Immun. 71:4034-4039.

Lehtolainen, T., Suominen, S., Kutila, T. and Pyorala, S. 2003. Effect of intramammary Escherichia coli endotoxin in early- vs. late-lactating dairy cows. J. Dairy Sci., 86: 23272333.

Li, P.S. and Wagne, W.C. 1983. In vivo and in vitro studies on the effect of adrenocorticotropic hormone or cortisol on the pituitary response to gonadotropin releasing hormone. Biol. Reprod., 29: 25.

Ohtsuka, H., Kudo, K., Mori, K., Nagai, F., Hatsugay, A., Tajima, M., Tamura, K., Hoshi, F., Koiwa, M. and Kawamura, S. 2001. Acute phase response in naturally occurring coliform mastitis, J. Vet. Med. Sci., 63: 675-678.

Oltenacu, P.A. and Algers, B. 2005. Selection for increased production 349 and the welfare of dairy cows; are new breeding goals needed. Ambio., 34: 308312.

Padmanabhan, V., Keech, C. and Convey, E.M., 1983. Cortisol inhibits and adrenocorticotropin has no effect on luteinizing hormone-releasing hormoneinduced release of luteinizing hormone from bovine pituitary cells in vitro. Endocrinology, 112: 1782.

PDADMAS (2011) PD-ADMAS news. Project directorate on animal disease monitoring and surveillance, January June, 1(1):8.

Riollet, C., Rainard, P. and Poutrel, B., 2000. Differential induction of complement fragment $\mathrm{C} 5 \mathrm{a}$ and inflammatory cytokines during intramammary infections with Escherichia coli and Staphylococcus aureus. Clin. Diagn. Lab. Immunol., 7(2): 161-167.

Santos, J.E.P., Cerri, R.L.A., Ballou, M.A., Higginbotham, G.E., Kirk, J.H., 2004. Effect of timing of first clinical mastitis occurrence on lactational and reproductive performance of Holstein dairy cows. Anim. Repro. Sci., 80: 3145.

Schrick, F.N., Hockett, M.E., Saxton, A.M., Lewis, M.J., Dowlen, H.H., Oliver and S.P. 2001. Influence of Subclinical Mastitis during Early Lactation on Reproductive Parameters. J. Dairy Sci., 84: 1407.

Seegers, H., Fourichon, C. and Beaudeau, F. 
2003. Production effects related to mastitis and mastitis economics in dairy cattle herds. Vet. Res., 34: 475-491.

Shoker A.S., Yang, H. and Murabit, M.A. (1997). Analysis of the in vitro effect of exogenous nitric oxide on human lymphocytes. Mol. Cell Biochem., 171: 75-83.

Singh, M., Sharma, A., Mittal D., Yadav P. and Charaya, G. 2016. Assessment of lactate dehydrogenase enzyme activity in milk as a marker for detection of subclinical mastitis [online]. J. Anim. Res., 6(2): 113-116.

Soliman, M., Ishioka, K., Kimura, K., Kushibiki, S. and Saito, M. 2002. Plasma leptin responses to lipopolysaccharide and tumor necrosis factor- $\alpha$ in cows. Jpn. J. Vet. Res., 50: 107-114.

Starzynski, D.J., Miyamoto, Y., Okuda K., 2000. Production of PGF $2 \alpha$ by cultured bovine endometrial cells in response to tumor necrosis factor $\alpha$ : cell type specificity and intracellular mechanisms. Biol. Repord., 62: 1160

Vangroenweghe, F., Lamote, I. and Burvenich, C. 2005. Physiology of the periparturient period and its relation to severity of clinical mastitis. Domest. Anim. Endocrinol., 29: 283-293.

Vangroenweghe, F., Rainard, P., Paape, M., Duchateau, L. and Burvenich, C. 2004. Increase of Escherichia coli inoculum doses induces faster innate immune response in primiparous cows. J. Dairy Sci., 87: 4132-4144.

Waldron, M. R., Nishida, T., Nonnecke, B. J. and Overton, T. R. (2003). Effect of lipopolysaccharide on indices of peripheral and hepatic metabolism in lactating cows. J. Dairy Sci. 86: 34473459.

\section{How to cite this article:}

Rachana Sharma, Manju Ashutosh, Panjab Singh, Sujata Pandita and Mahendra Singh. 2017. Inflammatory Mediators and Hormonal Changes in Subclinical and Clinically Affected Mastitis Cows. Int.J.Curr.Microbiol.App.Sci. 6(11): 620-627. doi: https://doi.org/10.20546/ijcmas.2017.611.074 